\title{
BMJ Open Nationwide cross-sectional study of the impact of chronic pain on an individual's employment: relationship with the family and the social support
}

\author{
Helena de Sola, ${ }^{1}$ Alejandro Salazar, ${ }^{1}$ María Dueñas, ${ }^{2}$ Begoña Ojeda, ${ }^{1}$ \\ Inmaculada Failde ${ }^{1}$
}

To cite: de Sola $\mathrm{H}$, Salazar A, Dueñas M, et al. Nationwide cross-sectional study of the impact of chronic pain on an individual's employment: relationship with the family and the social support. BMJ Open 2016;6:e012246. doi:10.1136/bmjopen-2016012246

- Prepublication history and additional material is available. To view please visit the journal (http://dx.doi.org/ 10.1136/bmjopen-2016012246).

Received 12 April 2016 Revised 17 August 2016 Accepted 29 September 2016

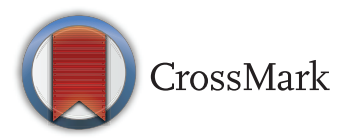

${ }^{1}$ Preventive Medicine and Public Health Area, University of Cadiz, Observatory of Pain Grünenthal FundationUniversity of Cadiz, Cadiz, Spain

${ }^{2}$ Salus Infirmorum Faculty of Nursing, University of Cadiz, Cadiz, Spain

Correspondence to Dr Helena de Sola: Helena.desola.p@gmail.com

\section{ABSTRACT}

Objectives: To determine the prevalence and the factors related to sick leave and job loss among individuals suffering from chronic pain (CP), and to analyse specifically the effect of family and social support on the individual's employment.

Design: Observational cross-sectional study.

Setting: Data were collected using structured computer-assisted telephone interviews between February and June 2011.

Participants: A nationwide study of 1543 Spanish adults of working age (<65), 213 of whom suffered from CP (pain suffered at least 4 or 5 days a week during the past 3 months, according to the criteria of the International Association for the Study of Pain (IASP)).

Main outcome measure: Information was collected regarding the individual's sociodemographic status, pain characteristics, healthcare use and satisfaction, limitations in daily activities, mood status, perception of the impact of pain on their families, and their satisfaction with the family and social support. To identify factors associated with sick leave and job loss among those suffering $\mathrm{CP}, 2$ logistic regression models were generated.

Results: The prevalence of sick leave due to $\mathrm{CP}$ in the general Spanish population was $4.21 \%(95 \% \mathrm{Cl}$ $3.2 \%$ to $5.2 \%$ ). Sick leave were more likely for individuals who considered their family were affected by their pain $(O R=2.18)$, needed help to dressing and grooming ( $O R=2.98)$, taking medication $(\mathrm{O}=2.18)$, had a shorter pain duration $(\mathrm{OR}=0.99)$ and higher educational level. The prevalence of job loss due to CP was $1.8 \%$ (95\% Cl $1.1 \%$ to $2.5 \%)$. It was related to feelings of sadness ( $O R=4.25)$, being unsatisfied with the care provided by health professionals $(\mathrm{OR}=2.60)$ and consulting a doctor more often due to $\mathrm{CP}(\mathrm{OR}=1.09)$.

Conclusions: $\mathrm{CP}$ is negatively associated with an individual's employment. This detrimental effect could be ameliorated if the factors related to sick leave and job loss provoked by CP are identified, especially those related to the effect of $\mathrm{CP}$ on the family and social environment.
Strengths and limitations of this study

- The study used data from a nationwide crosssectional survey of a Spanish population, representing a large sample: $\mathrm{N}=1543$.

- This is the first study to analyse the prevalence of sick leave and job loss due to chronic pain (CP) in the general Spanish population, and to identify factors related to the family environment that contribute to the sick leave taken and job loss of individuals with $\mathrm{CP}$.

- No data related to the individual's workload or presenteeism were obtained as it is difficult to assess these issues in telephone interviews.

\section{INTRODUCTION}

Chronic pain (CP) is a health problem that has reached worldwide epidemic proportions, affecting $19 \%^{1}$ of the population in Europe, and between $12 \%^{1}$ and $16.6 \%^{2}$ of the adult Spanish population. Studies carried out in various countries have shown that $\mathrm{CP}$ is associated with the individual's quality of life, significantly limiting their activities ${ }^{3} 4$ and impeding them from maintaining an independent lifestyle. ${ }^{1}$ In addition, individuals suffering from CP often experience mental disturbances ${ }^{25}$ and their family environment may also be severely affected. ${ }^{6}$

CP also influences an individual's employment, which may ultimately imply a significant financial burden. In Spain it has been estimated that people with CP are absent from the workplace $40 \%$ more than individuals who do not suffering from pain, and that they are $30 \%$ less productive. ${ }^{7}$ Likewise, various studies that have analysed the cost of CP have shown that the total costs represent $2 \%$ of the gross domestic product (GDP) in European countries, ${ }^{8}$ these costs including the direct costs associated to treatment and care, ${ }^{9}$ 
the indirect costs associated with sick leave and presenteeism, and the intangible costs related to quality of life. ${ }^{10-12}$ Indeed, in Spain it is estimated that the annual economic cost of CP is over $€ 3000$ million, $2.5 \%$ of the national GDP. ${ }^{13}$

Different factors have been associated with the effects of CP, such as the individual's working environment, ${ }^{14}$ the impact of pain on the family and poor family support. ${ }^{15}{ }^{16}$ Indeed, these latter factors have been associated with longer pain duration, more severe pain and more painful sites. ${ }^{2}$ Yet to the best of our knowledge, how these factors are related to the effects of CP on employment has been only assessed using a qualitative approach in individuals with back pain. ${ }^{17-19}$ Thus, in this study, we first aimed to analyse the prevalence of sick leave and job loss due to CP in the Spanish population. Subsequently, we set out to identify variables associated with these employment problems, particularly the effect of the family and the individual's perception of the social support they receive.

\section{METHODS}

Study design

This study is a secondary analysis of the data collected in a cross-sectional study that was carried out on a representative sample of the general Spanish population. The data were obtained with the aim of determining the prevalence of $\mathrm{CP}$ in this population. ${ }^{2}$

\section{Study population}

The original study included 1957 men and women at least 18 years of age. Here, we restricted the population to those of working age ( $>18$ and $<65$ years of age), a subsample of 1543 participants.

\section{Sampling method}

Multistage stratified sampling was used in this study, carrying out participant selection in four phases.

In the first sampling phase, strata were constructed according to the classification of the Spanish territory into four areas. This division was based on population ageing criteria that was derived from the ratio between the population older than 65 years of age and that younger than 15. The 'ageing' criterion was considered together with that of 'geographical area', given that both these factors have previously been demonstrated to be associated with pain prevalence. ${ }^{2021}$

During the second sampling phase, the number of towns within each stratum was determined, classifying the towns into four groups according to their population $(<5000 ; \quad 5000-20000 ; \quad 20000-50000 ; \quad>50000)$. Subsequently, towns were selected randomly in proportion to the total number in the group.

In the third phase, sampling units (telephone numbers) were selected randomly from each town chosen using the list of telephone numbers included in the Infobel España Office V.7.1 directory (Kapitol S.A.
Uccle, Brussels). In this way, our target population represented $\sim 90 \%$ of Spanish homes with a landline supplied by any telephone company, which in turn represented $80.6 \%$ of all Spanish homes. Therefore, the final percentage of the eligible Spanish population accessed was $72.5 \%$.

In a fourth sampling phase, the participants interviewed from their homes were selected randomly according to the previously established sex and age quotas. As a criterion for the choice of a respondent within the home, the first individual answering the phone was always chosen as long as they belonged to one of the strata of the population considered in the study and provided that this stratum was not already completed. If the person chosen was unavailable at that time, we asked them to arrange the interview for another more suitable moment. Before the interview, all participants included in the study gave their informed consent.

Three attempts were made to contact a home number before it was dismissed, calling at different times of the day. If no contact was established, the phone number was substituted by another in the same group.

The sample size necessary to achieve adequate statistical power was not specifically calculated for this study given that the data used were collected in an earlier study to determine the prevalence of CP in Spain in which the specific sample size required was calculated. ${ }^{2}$

\section{Data collection and measures}

Data were collected between February and June 2011 by trained interviewers that used structured computerassisted telephone interviews. The questionnaire employed was based on information from distinct surveys carried out previously in Spain (see online supplementary 1). ${ }^{22}{ }^{23}$ One screening question was used to identify the people with $\mathrm{CP}$ in accordance with the criteria of the International Association for the Study of Pain (IASP), and an individual was considered to have $\mathrm{CP}$ if he/she had suffered pain on at least 4 or 5 days a week during the past 3 months. Two questions were included in the questionnaire, to determine the frequency of sick leave in the study population, or whether the individual had left or lost their job in the last year due to CP: 'Have you needed to request any sick leave because of your pain in the last year?'; 'Have you left or lost your job because of your pain in the last year?' The responses to these questions were coded as 'yes' or 'no'.

The data collected included: sociodemographic data (age, sex and academic level); the characteristics of the pain (intensity, duration and localisation of the painful sites) and healthcare information (use of pain relief medication, number of medical consultations in the last year and opinion on the care received from the healthcare system). Pain intensity was measured using a scale of four categories: mild, moderate, severe and unbearable pain. ${ }^{24}$ Limitations in daily activities, and the effect of pain on the individual's mood and anxiety status were also explored through seven questions in the questionnaire. 
Table 1 Characteristics of the study population ( $\mathrm{N}=213$ people with chronic pain)

\begin{tabular}{|c|c|c|c|}
\hline Variables & Categories & $\mathbf{N}$ & $\begin{array}{l}\text { Per } \\
\text { cent }\end{array}$ \\
\hline \multicolumn{4}{|l|}{ Sociodemographic data } \\
\hline \multirow[t]{2}{*}{ Age $(\mathrm{N}=213)$} & $18-44$ & 91 & 42.7 \\
\hline & $45-64$ & 122 & 57.3 \\
\hline Age $(\mathrm{N}=211)$ & Mean (SD) & 47. & $(10.96)$ \\
\hline \multirow[t]{2}{*}{$\operatorname{Sex}(N=213)$} & Male & 49 & 23.0 \\
\hline & Female & 164 & 77.0 \\
\hline \multirow[t]{5}{*}{ Educational level $(\mathrm{N}=210)$} & No education received & 15 & 7.1 \\
\hline & Primary studies & 50 & 23.8 \\
\hline & Secondary studies & 70 & 33.3 \\
\hline & Vocational training & 36 & 17.1 \\
\hline & University studies & 39 & 18.6 \\
\hline \multicolumn{4}{|l|}{ Pain } \\
\hline \multirow{2}{*}{ Duration of pain (years, $\mathrm{N}=212$ ) } & Mean (SD) & \multicolumn{2}{|c|}{$8.99(9.40)$} \\
\hline & Median in years & \multicolumn{2}{|c|}{5} \\
\hline \multirow[t]{2}{*}{ Number of sites of pain $(\mathrm{N}=212)$} & 1 location & 120 & 56.6 \\
\hline & More than 1 location & 92 & 43.4 \\
\hline \multirow[t]{8}{*}{ The most affected pain site $(\mathrm{N}=212)$} & Widespread pain & 34 & 16.0 \\
\hline & Head & 25 & 11.8 \\
\hline & Neck (cervical vertebrae) & 17 & 8.0 \\
\hline & Back & 49 & 23.1 \\
\hline & Limbs and/or joints & 70 & 33.3 \\
\hline & Chest & 4 & 1.9 \\
\hline & Abdomen & 8 & 3.8 \\
\hline & Other & 5 & 2.4 \\
\hline \multirow[t]{4}{*}{ Pain intensity $(\mathrm{N}=211)$} & Slight or very slight & 11 & 5.2 \\
\hline & Moderate & 94 & 44.5 \\
\hline & Severe & 75 & 35.5 \\
\hline & Unbearable & 31 & 14.7 \\
\hline $\begin{array}{l}\text { Number of medical pain consultations in the last year } \\
(\mathrm{N}=199)\end{array}$ & Mean (SD) & \multicolumn{2}{|c|}{$3.60(4.139)$} \\
\hline \multirow[t]{2}{*}{ Currently taking pain relief medication $(\mathrm{N}=213)$} & No & 67 & 31.5 \\
\hline & Yes & 146 & 68.5 \\
\hline \multirow[t]{5}{*}{ Opinion on the care received $(\mathrm{N}=196)$} & Very unsatisfied & 12 & 6.1 \\
\hline & Unsatisfied & 21 & 10.7 \\
\hline & Neither satisfied nor dissatisfied & 35 & 17.9 \\
\hline & Satisfied & 85 & 43.4 \\
\hline & Very satisfied & 43 & 21.9 \\
\hline \multicolumn{4}{|l|}{ Mood } \\
\hline \multirow[t]{5}{*}{ Sadness $(\mathrm{N}=213)$} & Not at all & 62 & 29.1 \\
\hline & A little & 37 & 17.4 \\
\hline & Some & 51 & 23.9 \\
\hline & Quite a lot & 38 & 17.8 \\
\hline & A lot & 25 & 11.7 \\
\hline \multirow[t]{5}{*}{ Anxiety and distress $(\mathrm{N}=212)$} & Not at all & 64 & 30.0 \\
\hline & A little & 41 & 19.3 \\
\hline & Some & 41 & 19.3 \\
\hline & Quite a lot & 39 & 18.4 \\
\hline & A lot & 27 & 12.7 \\
\hline \multicolumn{4}{|l|}{ Family and social environment } \\
\hline \multirow{5}{*}{$\begin{array}{l}\text { The individual considers that his/her pain affects his/her } \\
\text { family }(\mathrm{N}=212)\end{array}$} & Not at all & 111 & 52.4 \\
\hline & A little & 27 & 12.7 \\
\hline & Some & 39 & 18.4 \\
\hline & Quite a lot & 27 & 12.7 \\
\hline & A lot & 8 & 3.8 \\
\hline Impact on relationships with friends $(\mathrm{N}=212)$ & $\begin{array}{l}\text { The relationship has been lost because of } \\
\text { my pain }\end{array}$ & 8 & 3.8 \\
\hline & The relationship has deteriorated & 39 & 18.4 \\
\hline
\end{tabular}


Table 1 Continued

\begin{tabular}{|c|c|c|c|}
\hline Variables & Categories & $\mathbf{N}$ & $\begin{array}{l}\text { Per } \\
\text { cent }\end{array}$ \\
\hline \multirow{7}{*}{$\begin{array}{l}\text { Satisfaction with the support received } \\
\text { from the family }(N=213)\end{array}$} & Nothing has changed in the relationship & 164 & 77.4 \\
\hline & The relationship has improved & 1 & 0.5 \\
\hline & Very unsatisfied & 4 & 1.9 \\
\hline & Unsatisfied & 7 & 3.3 \\
\hline & Neither satisfied nor dissatisfied & 38 & 17.8 \\
\hline & Satisfied & 91 & 42.7 \\
\hline & Very satisfied & 73 & 34.3 \\
\hline \multicolumn{4}{|l|}{ Employment environment } \\
\hline \multirow[t]{2}{*}{ Sick leave $(\mathrm{N}=206)$} & No & 141 & 66.2 \\
\hline & Yes & 65 & 31.6 \\
\hline \multirow{2}{*}{ Left or lost employment $(\mathrm{N}=207)$} & No & 179 & $84 \%$ \\
\hline & Yes & 28 & 13.5 \\
\hline
\end{tabular}

Figure 1 Limitations to daily life activities among the study individuals.

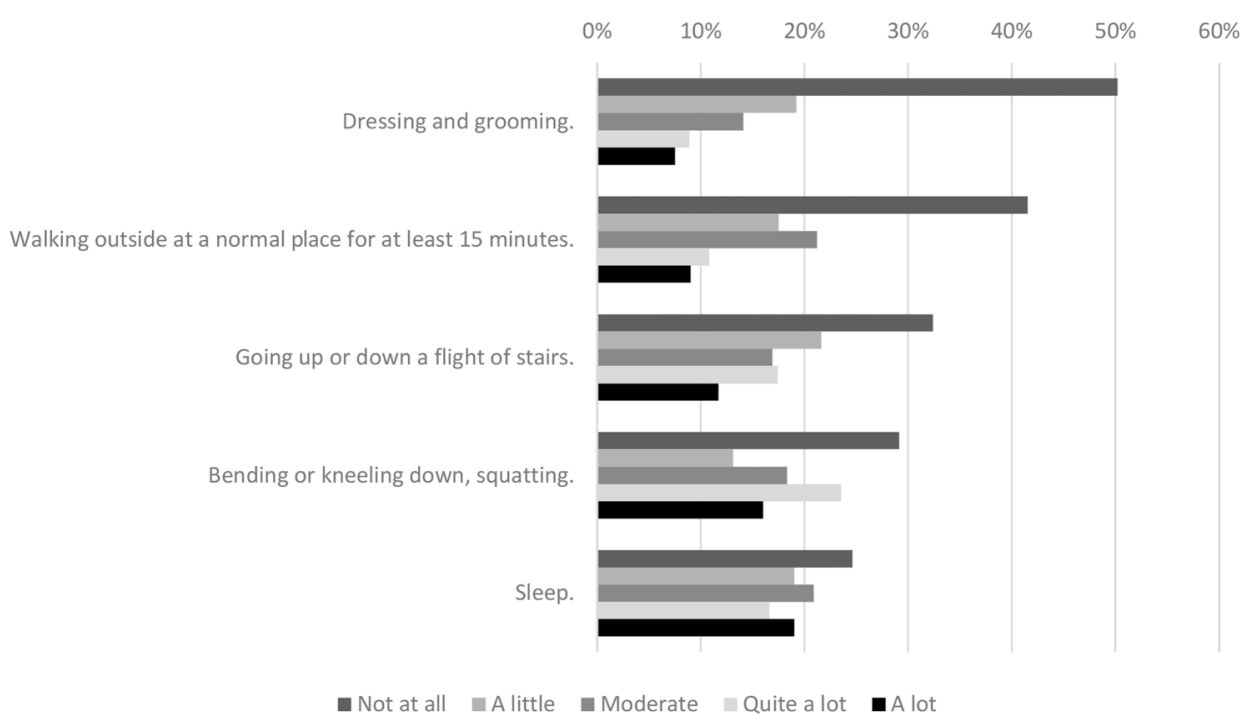

In addition, the impact of $\mathrm{CP}$ on the individual's family and their relationships with their friends were evaluated through two questions: 'How do you consider your pain affects your family?'; and 'Has your pain affected your relationships with friends?' To define the individual's satisfaction with the family support they receive, they were also asked: 'Are you satisfied with the support provided by your family?"

\section{Statistical analysis}

A descriptive analysis of the variables studied was performed, calculating the frequency, central tendency and dispersion. Differences between the groups were evaluated with the $\chi^{2}$ test for categorical variables, and a Mann-Whitney $\mathrm{U}$ test was used to test continuous variables with a non-normal distribution. For all the tests, $\mathrm{p} \leq 0.05$ was considered significant.

Two logistic regression models were set-up to analyse the association between pain and sick leave (model 1), and that between pain and the loss of employment (model 2), targeting sick leave and job loss as the dependent variable. The criteria used to select the covariates included in these models were both statistical (a significant difference observed in the bivariate analysis: $\mathrm{p}<0.05$ ) and clinical (previously shown in the literature). In addition, to facilitate the interpretation of the model, the categories of the variables related to functional limitations, mood and the effect of CP on the individual's family were dichotomised as 'yes' or 'no'. Similarly, the variable related to family support was grouped into two categories: 'satisfied' or 'unsatisfied'.

\section{RESULTS}

General characteristics of individuals suffering from chronic pain

Of the 1543 participants interviewed (response rate $36.9 \%), 213$ suffered from CP according to the criteria used in this study, their average age was 47.9 years (SD 10.9 ) and $77 \%$ of them were women. Among the individuals suffering CP, $43.4 \%$ experienced pain at multiple locations, the most common sites being the limbs and 
Table 2 Bivariate analysis of the factors related to sick leave request

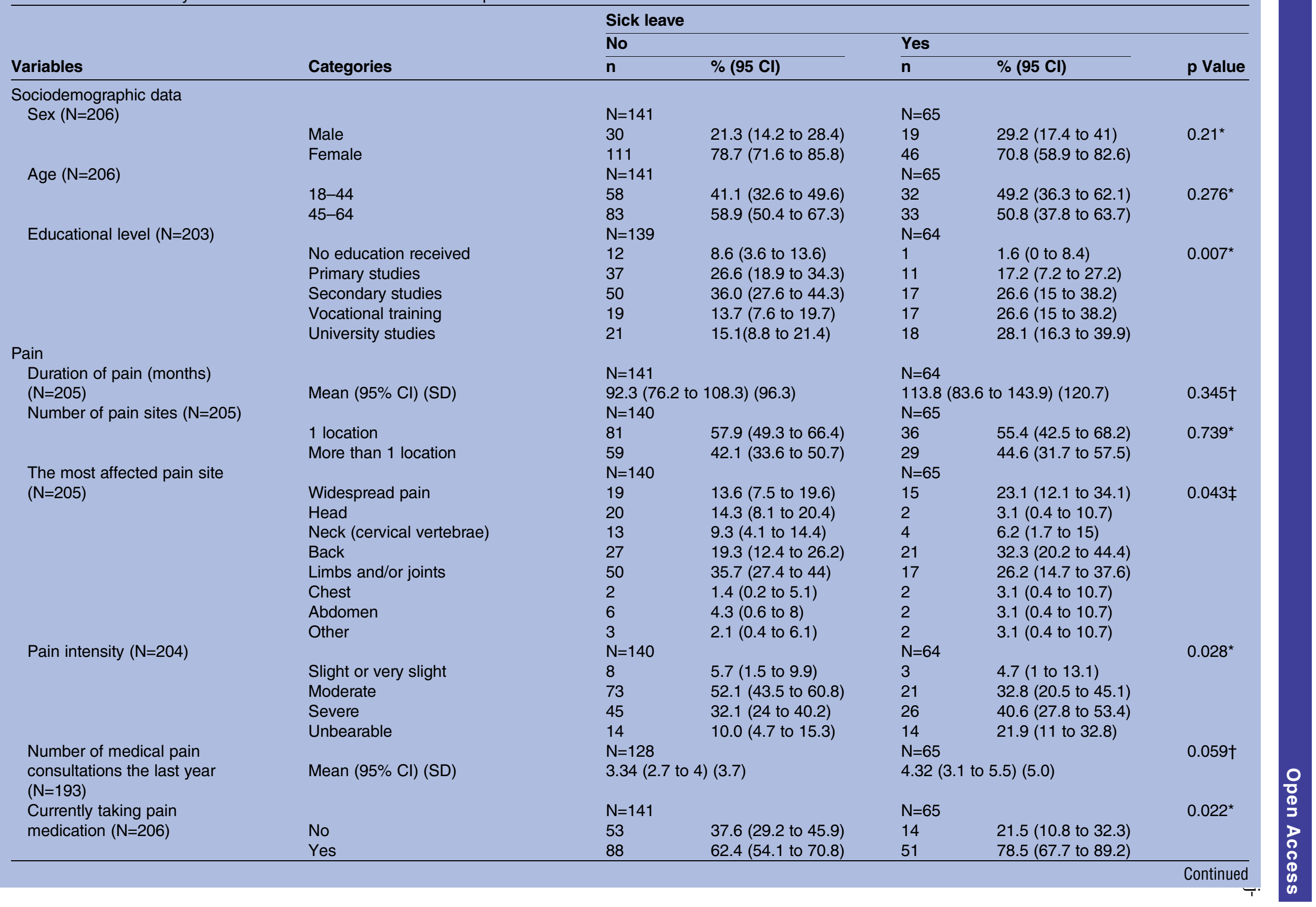




\begin{tabular}{|c|c|c|c|c|c|c|}
\hline \multirow[b]{3}{*}{ Variables } & \multirow[b]{3}{*}{ Categories } & \multicolumn{5}{|c|}{ Sick leave } \\
\hline & & \multicolumn{2}{|l|}{ No } & \multicolumn{2}{|l|}{ Yes } & \multirow[b]{2}{*}{ p Value } \\
\hline & & $\bar{n}$ & $\%(95 \mathrm{Cl})$ & $\mathrm{n}$ & $\%(95 \mathrm{Cl})$ & \\
\hline \multirow{6}{*}{$\begin{array}{l}\text { Opinion on the care received } \\
(\mathrm{N}=190)\end{array}$} & & $\mathrm{N}=128$ & & $\mathrm{~N}=62$ & & $0.149^{*}$ \\
\hline & Very unsatisfied & 5 & $3.9(1.3$ to 8.9$)$ & 7 & $11.3(2.6$ to 20$)$ & \\
\hline & Unsatisfied & 15 & 11.7 (5.7 to 17.7$)$ & 6 & 9.7 (1.5 to 17.8$)$ & \\
\hline & Neither satisfied nor dissatisfied & 20 & 15.6 (8.9 to 22.3$)$ & 13 & $21.0(10$ to 31.9$)$ & \\
\hline & Satisfied & 62 & 48.4 (39.4 to 57.5$)$ & 21 & 33.9 (21.3 to 46.4$)$ & \\
\hline & Very satisfied & 26 & 20.3 (12.9 to 27.7$)$ & 15 & $24.2(12.7$ to 35.7$)$ & \\
\hline \multicolumn{7}{|l|}{ Mood } \\
\hline \multirow[t]{6}{*}{ Sadness $(N=206)$} & & $N=141$ & & $\mathrm{~N}=65$ & & $0.029^{*}$ \\
\hline & Not at all & 49 & 34.8 (26.5 to 43$)$ & 12 & 18.5 (8.7 to 30$)$ & \\
\hline & A little & 23 & 16.3 (9.8 to 22.7$)$ & 12 & 18.5 (8.7 to 30$)$ & \\
\hline & Some & 35 & 24.8 (17.3 to 32.3$)$ & 16 & 24.6 (14.1 to 37.5$)$ & \\
\hline & Quite a lot & 24 & 17.0 (10.5 to 23.6$)$ & 12 & $18.5(8.7$ to 30$)$ & \\
\hline & A lot & 10 & $7.1(2.5$ to 11.7$)$ & 13 & $20.0(10$ to 31.9$)$ & \\
\hline \multirow[t]{6}{*}{ Anxiety and distress $(\mathrm{N}=205)$} & & $\mathrm{N}=141$ & & $\mathrm{~N}=64$ & & $0.020^{*}$ \\
\hline & Not at all & 51 & $36.2(27.9$ to 44.4$)$ & 12 & 18.8 (8.4 to 29.1$)$ & \\
\hline & A little & 26 & 18.4 (11.7 to 25.2$)$ & 12 & 18.8 (8.4 to 29.1$)$ & \\
\hline & Some & 27 & $19.1(12.3$ to 26$)$ & 14 & 21.9 (11 to 32.8$)$ & \\
\hline & Quite a lot & 26 & 18.4 (11.7 to 25.2$)$ & 12 & 18.8 (8.4 to 29.1 ) & \\
\hline & A lot & 11 & 7.8 (3 to 12.6$)$ & 14 & 21.9 (11 to 32.8$)$ & \\
\hline \multicolumn{7}{|l|}{ Family and social environment } \\
\hline The individual considers that & & $\mathrm{N}=141$ & & $\mathrm{~N}=65$ & & $0.056^{*}$ \\
\hline his/her pain affects his/her & Not at all & 81 & 57.4 (49 to 66$)$ & 27 & 41.5 (28.8 to 54.3$)$ & \\
\hline \multirow[t]{4}{*}{ family $(\mathrm{N}=206)$} & A little & 17 & $12.1(6.3$ to 17.8$)$ & 10 & 15.4 (5.8 to 24.9$)$ & \\
\hline & Some & 24 & 17.0 (10.5 to 23.6$)$ & 14 & 21.5 (10.8 to 32.3 ) & \\
\hline & Quite a lot & 12 & 8.5 (3.5 to 13.5$)$ & 13 & $20.0(9.5$ to 30.5$)$ & \\
\hline & A lot & 7 & 5.0 (1 to 8.9$)$ & 1 & $1.5(0$ to 8.3$)$ & \\
\hline Impact on relationships with & & $\mathrm{N}=140$ & & $\mathrm{~N}=65$ & & $0.202 \ddagger$ \\
\hline \multirow[t]{4}{*}{ friends $(\mathrm{N}=205)$} & $\begin{array}{l}\text { The relationship has been lost } \\
\text { because of the pain }\end{array}$ & 4 & $2.9(0.8$ to 7.1$)$ & 3 & 4.6 (0.9 to 12.9$)$ & \\
\hline & The relationship has deteriorated & 22 & 15.7 (9.3 to 22.1$)$ & 15 & $23.1(12.1$ to 34.1$)$ & \\
\hline & $\begin{array}{l}\text { Nothing has changed in the } \\
\text { relationship }\end{array}$ & 114 & 81.4 (14.6 to 88.2$)$ & 46 & 70.8 (59 to 82.6$)$ & \\
\hline & The relationship has improved & 0 & 0.0 & 1 & $1.5(0$ to 8.3$)$ & \\
\hline Satisfaction with the support & & $N=141$ & & $\mathrm{~N}=65$ & & $0.834 \ddagger$ \\
\hline received from the family & Very unsatisfied & 3 & $2.1(0.4$ to 6.1$)$ & 1 & $1.5(0$ to 8.3$)$ & \\
\hline \multirow{4}{*}{$(\mathrm{N}=206)$} & Unsatisfied & 4 & $2.8(0.8$ to 7.1$)$ & 3 & $4.6(0.9$ to 12.9$)$ & \\
\hline & Neither satisfied nor dissatisfied & 23 & 16.3 (9.8 to 22.8$)$ & 14 & 21.5 (10.8 to 32.3$)$ & \\
\hline & Satisfied & 61 & 43.3 (34.7 to 51.8$)$ & 27 & 41.5 (28.8 to 54.3$)$ & \\
\hline & Very satisfied & 50 & 35.5 (27.2 to 43.7$)$ & 20 & 30.8 (18.8 to 42.7$)$ & \\
\hline
\end{tabular}


oints, and $68.5 \%$ were taking pain relief medication. The mean duration of pain was $\sim 9$ years (SD 9.4; median 5 years: table 1 ) and about $70 \%$ of respondents with CP felt sad and/or anxious because of their pain, reporting that their pain affected activities such as bending down, kneeling down, squatting and sleeping (figure 1). In addition, $47.6 \%$ of those suffering CP considered that their pain affected their family environment and $22.2 \%$ reported that CP had affected the relationship with their friends. Moreover, $77 \%$ of the people were generally satisfied or very satisfied with the help received from their relatives (table 1).

\section{Characteristics of the individuals who requested sick leave} and related variables

It is noteworthy that $31.6 \%$ of those respondents suffering $\mathrm{CP}$ reported having been on sick leave in the last year because of their CP, representing a prevalence of $4.21 \%$ of the Spanish population (95\% CI 3.2\% to 5.2\%). This prevalence was higher in women $(2.98 \%$; $95 \%$ CI $2.1 \%$ to $3.9 \%)$ than in men $(1.23 \% ; 95 \%$ CI $0.6 \%$ to $1.8 \%$; $\mathrm{p}=0.001$ ), and notably, participants with a higher educational level, those with severe or unbearable pain
$(40.6 \%)$, and those with pain located principally in their back $(32.3 \%)$ took sick leave more often (table 2). In addition, $78.5 \%$ of people who requested sick leave were taking pain relief medication, while $64.6 \%$ needed help in grooming and dressing (figure 2), and $81.5 \%$ felt sad and/or anxious because of their pain (table 2). The individuals who had taken sick leave did not appear to have experienced a deterioration in their relationship with friends, nor were they less satisfied with the level of support provided by the family, although they did perceive a greater effect of pain on their family.

The multivariate analysis of the variables associated to sick leave in the study population showed that those individuals who considered that their pain affected their families $(\mathrm{OR}=2.18,95 \%$ CI 1.10 to 4.34), those who needed help in grooming or dressing $(\mathrm{OR}=2.98$, 95\% CI 1.49 to 5.98$)$, those currently taking pain medication $(\mathrm{OR}=2.18,95 \%$ CI 1.01 to 4.72$)$ and those with a higher educational level, were more likely to take sick leave because of their pain. In contrast, a longer duration of $\mathrm{CP}$ was associated with the need for less sick leave among the individuals studied ( $\mathrm{OR}=0.99,95 \%$ CI 0.99 to 1.00; table 3).

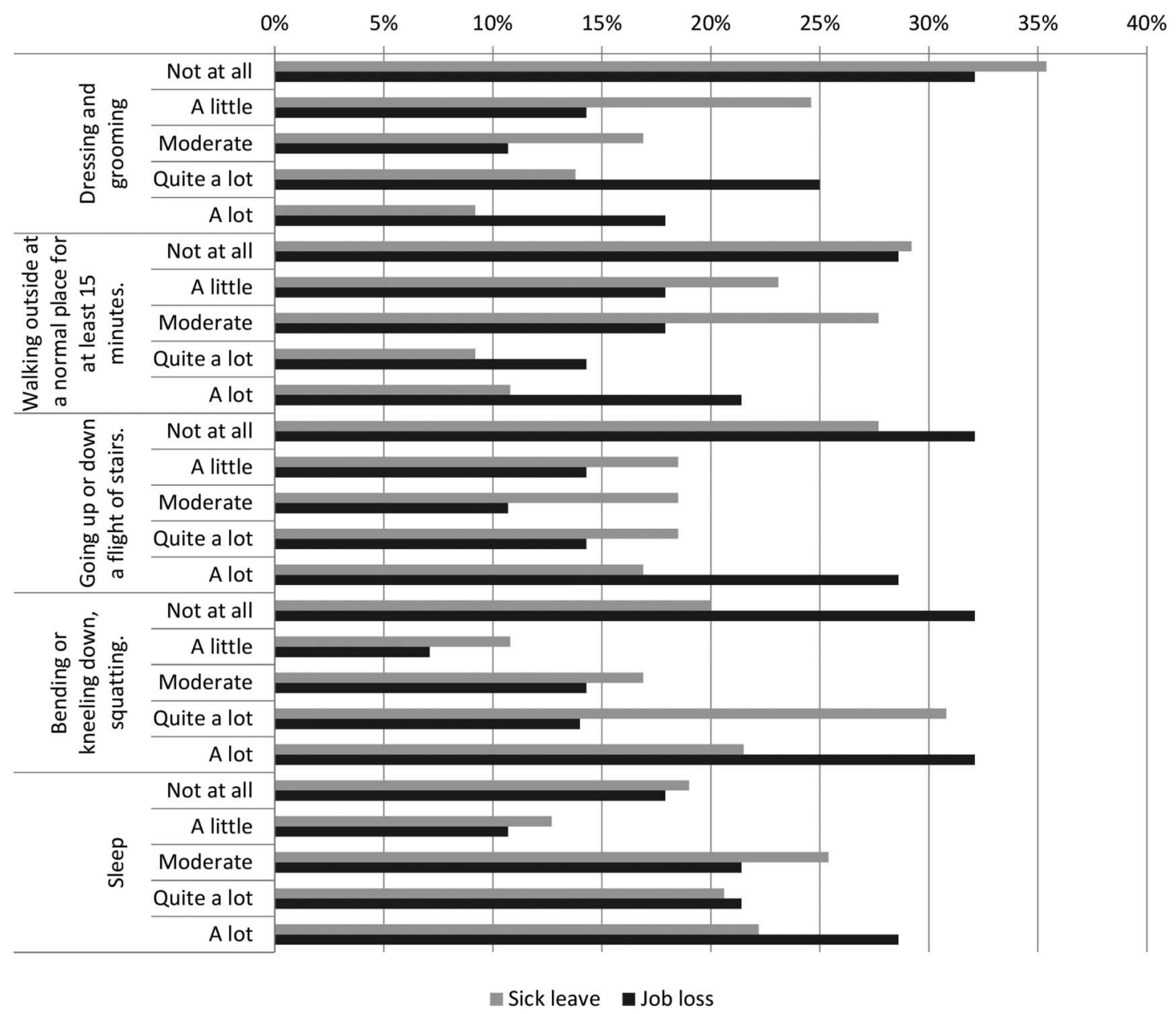

Figure 2 Association between daily life activities and requests for sick leave, and leaving or the loss of employment. 
Table 3 Multivariate analysis of the factors related to sick leave

\begin{tabular}{|c|c|c|c|}
\hline \multicolumn{4}{|c|}{ Sick leave $(\mathrm{N}=202)$} \\
\hline Variables & $\begin{array}{l}\text { Wald } \\
\text { statistic }\end{array}$ & OR $(95 \% \mathrm{Cl})$ & p Value \\
\hline \multicolumn{4}{|c|}{ Educational level } \\
\hline \multicolumn{4}{|c|}{ No education received* } \\
\hline $\begin{array}{l}\text { Primary } \\
\text { studies }\end{array}$ & 1.44 & 3.89 (0.42 to 35.74$)$ & 0.230 \\
\hline $\begin{array}{l}\text { Secondary } \\
\text { studies }\end{array}$ & 1.94 & 4.74 (0.53 to 42.34$)$ & 0.164 \\
\hline $\begin{array}{l}\text { Vocational } \\
\text { training }\end{array}$ & 5.61 & 14.71 (1.59 to 136.24$)$ & 0.018 \\
\hline $\begin{array}{l}\text { University } \\
\text { studies }\end{array}$ & 6.13 & 16.70 (1.80 to 155.07$)$ & 0.013 \\
\hline \multicolumn{4}{|c|}{$\begin{array}{l}\text { The individual needs assistance in grooming and dressing } \\
\text { because of their pain }\end{array}$} \\
\hline $\mathrm{No}^{*}$ & & & 0.002 \\
\hline Yes & 9.50 & 2.98 (1.49 to 5.98$)$ & \\
\hline \multicolumn{4}{|c|}{$\begin{array}{l}\text { The individual considers that his/her pain affects his/her } \\
\text { family }\end{array}$} \\
\hline $\mathrm{No}^{*}$ & & & 0.026 \\
\hline Yes & 4.97 & 2.18 (1.10 to 4.34$)$ & \\
\hline $\begin{array}{l}\text { Duration of } \\
\text { pain (months) }\end{array}$ & 4.16 & 0.99 (0.99 to 1.00$)$ & 0.041 \\
\hline \multicolumn{4}{|c|}{$\begin{array}{l}\text { The individual is currently taking pain relief medication } \\
\mathrm{No}^{*}\end{array}$} \\
\hline Yes & 3.96 & 2.18 (1.01 to 4.72$)$ & 0.047 \\
\hline
\end{tabular}

\section{Characteristics of the people who had left or lost their jobs and the related variables}

Of the individuals suffering from CP, $13.5 \%$ reported having lost or left their jobs because of their pain, representing a prevalence of $1.81 \%$ of the Spanish population (95\% CI 1.1 to 2.5$)$. This prevalence was higher in women $(1.23 \%$ vs $0.58 \%$ : $p=0.088)$. Among these individuals, it was particularly notable that $42.9 \%$ rated their pain as unbearable, $67.9 \%$ needed help in grooming and dressing (figure 2) and more than half $(57.7 \%)$ were dissatisfied with the care provided by the healthcare system. Likewise, a very high percentage of these people felt sad (89\%) or anxious (85.7\%) because of their pain, and $44.4 \%$ reported that the relationship with their friends had deteriorated, while $35.7 \%$ considered that their pain had an impact on their family. However, only $10.7 \%$ indicated that they were not satisfied with the help provided by the family (table 4 ).

In the multivariate analysis of the variables associated with the loss of employment, only those individuals with $\mathrm{CP}$ who felt sad because of their pain $(\mathrm{OR}=4.25,95 \%$ CI 0.95 to 19.02 ), those who were not satisfied with the care provided by healthcare professionals $(\mathrm{OR}=2.60,95 \%$ CI 6.25 to 1.08 ) and those who had consulted a doctor more often because of their pain $(\mathrm{OR}=1.09,95 \%$ CI 1.00 to 1.19 ) were more likely to have lost or left their job (table 5).

\section{DISCUSSION}

This study analyses the relationship of CP with employment among the Spanish general population. Specifically, the prevalence of sick leave due to CP was assessed and in addition, the loss of employment due to CP was also evaluated. To the best of our knowledge, this is the first study to analyse how the family environment affects these two employment-related issues in individuals suffering from CP. The results obtained reveal that there is a significant relationship between CP and the individual's capacity to work, meaning that over $4 \%$ of the Spanish population in working age requested sick leave in the last year and that nearly $2 \%$ lost their jobs as a result of the CP suffered. It is also noteworthy that almost a third of the individuals suffering CP needed to take sick leave and that over $10 \%$ lost their jobs as a result of their CP. Although these figures are lower than those reported elsewhere, ${ }^{7} 142526$ they are particular significant if we take into consideration the associated social and economic burden. ${ }^{10-12} 27$

It is notable that among the factors associated with sick leave in the study, individuals whose CP produced greater physical limitations (incapable to groom themselves or get dressed without help), as well as those who perceived that CP was affecting their family environment, were the individuals at greater risk of requesting sick leave. Thus, the perception of the effect of pain on the family is associated with the individual's professional life. These results are consistent with other findings where the physical limitations experienced by patients produce greater reliance on care and assistance, which is mostly provided by the family. ${ }^{28}$ As a consequence, these demands produce feelings of dependency and a reduced sense of autonomy and/or self-confidence, ${ }^{29}$ which could affect an individual's performance in the workplace. However, this hypothesis should be tested more directly.

Our results are consistent with some previous analyses of the factors associated with absenteeism in individuals suffering $\mathrm{CP}^{30}{ }^{31}$ whereby those who take pain relief medication and that had a shorter duration of pain are likely to take more sick leave. In line with our results, employees who stay on sick leave due to neck or back pain appear to take higher doses of medication than other people. ${ }^{32}$ Moreover, it has been proposed that the longer pain is experienced, the better individuals can adapt to CP, reorganising their lives and learning to accept their pain, making them better able to perform their jobs. ${ }^{30}$ However, pain intensity did not appear to be related to sick leave here, in contrast to an earlier report ${ }^{12}$ but in accordance with another study in which fear avoidance, pain catastrophising and pain selfefficacy belief were other psychological variables associated with the ability to work. ${ }^{33}$

It has been reported that at the same intensity of pain, how individuals deal with CP depends on their level of education. ${ }^{34}$ Indeed, a lower educational level apparently predicts an increased risk of sick leave. ${ }^{30}$ However, 
Table 4 Bivariate analysis of the factors related to leaving or losing employment

\begin{tabular}{|c|c|c|c|c|c|c|}
\hline \multirow[b]{3}{*}{ Variables } & \multirow[b]{3}{*}{ Categories } & \multicolumn{5}{|c|}{ Left or lost employment } \\
\hline & & \multicolumn{2}{|l|}{ No } & \multicolumn{2}{|c|}{ Yes } & \multirow[b]{2}{*}{ p Value } \\
\hline & & $\bar{n}$ & $\%(95 \% \mathrm{Cl})$ & $\bar{n}$ & $\%(95 \% \mathrm{Cl})$ & \\
\hline \multicolumn{7}{|l|}{ Sociodemographic data } \\
\hline \multirow{3}{*}{ Sex $(N=207)$} & & $\mathrm{N}=1$ & & $\mathrm{~N}=$ & & $0.257^{\star}$ \\
\hline & Male & 40 & 22.3 (16.5 to 29.2$)$ & 9 & 32.1 (15.9 to 52.4$)$ & \\
\hline & Female & 139 & 77.7 (70.8 to 83.5$)$ & 19 & 67.9 (47.6 to 84.1$)$ & \\
\hline \multirow[t]{3}{*}{ Age $(\mathrm{N}=207)$} & & $\mathrm{N}=1$ & & $\mathrm{~N}=$ & & $0.735^{\star}$ \\
\hline & $18-44$ & 77 & 43.0 (35.5 to 50.5$)$ & 13 & 46.4 (26.2 to 66.7$)$ & \\
\hline & $45-64$ & 102 & 57.0 (49.5 to 64.5$)$ & 15 & 53.6 (33.3 to 73.8 ) & \\
\hline \multirow[t]{6}{*}{ Educational level ( $\mathrm{N}=204)$} & & $\mathrm{N}=1$ & & $\mathrm{~N}=$ & & $0.860^{*}$ \\
\hline & No education received & 13 & 7.4 (3.2 to 11.5$)$ & 1 & 3.6 (0.1 to 18.3$)$ & \\
\hline & Primary studies & 41 & 23.3 (16.8 to 29.8$)$ & 7 & 25.0 (7.2 to 42.8$)$ & \\
\hline & Secondary studies & 59 & 33.5 (26.3 to 40.8$)$ & 8 & 28.6 (10.1 to 47.1$)$ & \\
\hline & Vocational training & 31 & 17.6 (11.7 to 23.5$)$ & 5 & $17.9(6.1$ to 36.9$)$ & \\
\hline & University studies & 32 & 18.2 (12.2 to 24.2$)$ & 7 & 25.0 (7.2 to 42.8$)$ & \\
\hline \multicolumn{7}{|l|}{ Pain } \\
\hline \multirow[t]{2}{*}{ Duration of pain (months) $(\mathrm{N}=206)$} & & \multicolumn{2}{|c|}{$\mathrm{N}=179$} & \multicolumn{2}{|c|}{$\mathrm{N}=27$} & $0.989 \dagger$ \\
\hline & Mean $(95 \% \mathrm{Cl})(\mathrm{SD})$ & \multicolumn{2}{|c|}{$\begin{array}{l}106.89 \text { (89.9 to } 123.8) \\
(114.9)\end{array}$} & \multicolumn{2}{|c|}{$\begin{array}{l}105.04 \text { (62.6 to } 147.5) \\
(107.4)\end{array}$} & \\
\hline \multirow{3}{*}{ Number of pain sites $(\mathrm{N}=206)$} & & \multicolumn{2}{|c|}{$\mathrm{N}=178$} & \multicolumn{2}{|c|}{$\mathrm{N}=28$} & $0.185^{\star}$ \\
\hline & 1 location & 97 & 54.5 (46.9 to 62.1$)$ & 19 & 67.9 (48.8 to 86.9 ) & \\
\hline & More than 1 location & 81 & 45.5 (37.9 to 53.1 ) & 9 & 32.1 (13.1 to 51.2$)$ & \\
\hline \multirow[t]{10}{*}{ The most affected pain site $(\mathrm{N}=206)$} & & \multicolumn{2}{|c|}{$\mathrm{N}=178$} & \multicolumn{2}{|c|}{$\mathrm{N}=28$} & $0.249 \ddagger$ \\
\hline & Widespread pain & 29 & 16.3 (10.6 to 22.0$)$ & 5 & 17.9 (6.1 to 36.9 ) & \\
\hline & Head & 23 & $12.9(7.7$ to 18.1$)$ & 1 & $3.6(0.1$ to 18.3$)$ & \\
\hline & Neck (cervical vertebrae) & 16 & $9.0(4.5$ to 13.5$)$ & 1 & $3.6(0.1$ to 18.3$)$ & \\
\hline & Back & 38 & 21.3 (15.0 to 27.6$)$ & 9 & 32.1 (13.1 to 51.2$)$ & \\
\hline & Limbs and/or joints & 61 & 34.3 (27.0 to 41.5$)$ & 7 & 25.0 (7.2 to 42.8$)$ & \\
\hline & Chest & 2 & $1.1(0.1$ to 4.0$)$ & 1 & $3.6(0.1$ to 18.3$)$ & \\
\hline & Abdomen & 5 & $2.8(0.9$ to 6.4$)$ & 3 & 10.7 (2.3 to 28.2$)$ & \\
\hline & Other & 4 & $2.2(0.6$ to 5.7$)$ & 1 & $3.6(0.1$ to 18.3$)$ & \\
\hline & & \multicolumn{2}{|c|}{$\mathrm{N}=178$} & $\mathrm{~N}=$ & & \\
\hline \multirow[t]{4}{*}{ Pain intensity $(\mathrm{N}=206)$} & Slight or very slight & 9 & $5.1(1.6$ to 8.6$)$ & 2 & 7.1 (0.9 to 23.5$)$ & $0.000 \ddagger$ \\
\hline & Moderate & 90 & 50.6 (42.9 to 58.2$)$ & 3 & 10.7 (2.3 to 28.2$)$ & \\
\hline & Severe & 61 & $34.3(27.0$ to 41.5$)$ & 11 & 39.3 (19.4 to 59.2$)$ & \\
\hline & Unbearable & 18 & $10.1(5.4$ to 14.8$)$ & 12 & 42.9 (22.7 to 63.0$)$ & \\
\hline Number of medical pain consultations last year & & $\mathrm{N}=1$ & & $\mathrm{~N}=$ & & $0.400 \dagger$ \\
\hline$(\mathrm{N}=193)$ & Mean $(95 \% \mathrm{Cl})(\mathrm{SD})$ & 3.36 & 3 to 3.9$)(3.6)$ & 5.3 & 2.8 to 7.8$)(6.4)$ & \\
\hline Currently taking pain relief medication $(\mathrm{N}=207)$ & & $\mathrm{N}=1$ & & $\mathrm{~N}=$ & & $0.057^{\star}$ \\
\hline & No & 62 & $34.6(27.4$ to 41.9$)$ & 5 & $17.9(6.1$ to 36.9$)$ & \\
\hline & Yes & 117 & 65.4 (58.1 to 72.6 ) & 23 & 82.1 (63.1 to 93.9$)$ & \\
\hline & & & & & & Continued \\
\hline
\end{tabular}




\begin{tabular}{|c|c|c|c|c|c|c|}
\hline \multirow[b]{3}{*}{ Variables } & \multirow[b]{3}{*}{ Categories } & \multicolumn{5}{|c|}{ Left or lost employment } \\
\hline & & \multicolumn{2}{|l|}{ No } & \multicolumn{2}{|l|}{ Yes } & \multirow[b]{2}{*}{ p Value } \\
\hline & & $\mathbf{n}$ & $\%(95 \% \mathrm{Cl})$ & $\bar{n}$ & $\%(95 \% \mathrm{Cl})$ & \\
\hline \multirow[t]{6}{*}{ Opinion on the care received $(\mathrm{N}=190)$} & & $\mathrm{N}=164$ & & $\mathrm{~N}=26$ & & $0.002 \ddagger$ \\
\hline & Very unsatisfied & 6 & $3.7(0.5$ to 6.8$)$ & 6 & 23.1 (9.0 to 43.6$)$ & \\
\hline & Unsatisfied & 19 & $11.6(6.4$ to 16.8$)$ & 2 & 7.7 (0.9 to 25.1$)$ & \\
\hline & Neither satisfied nor dissatisfied & 27 & $16.5(10.5$ to 22.4$)$ & 7 & 26.9 (8.0 to 45.9$)$ & \\
\hline & Satisfied & 76 & 46.3 (38.4 to 54.3 ) & 7 & 26.9 (8.0 to 45.9$)$ & \\
\hline & Very satisfied & 36 & 22.0 (15.3 to 28.6$)$ & 4 & 15.4 (4.4 to 34.9$)$ & \\
\hline \multicolumn{7}{|l|}{ Mood } \\
\hline \multirow[t]{6}{*}{ Sadness $(\mathrm{N}=207)$} & & $N=179$ & & $N=28$ & & $<0.001 \ddagger$ \\
\hline & Not at all & 58 & 32.4 (25.3 to 39.5$)$ & 3 & 10.7 (2.3 to 28.2 ) & \\
\hline & A little & 31 & $17.3(11.5$ to 23.1$)$ & 3 & 10.7 (2.3 to 28.2$)$ & \\
\hline & Some & 47 & $26.3(19.5$ to 33.0$)$ & 4 & $14.3(4.0$ to 32.7$)$ & \\
\hline & Quite a lot & 29 & $16.2(10.5$ to 21.9$)$ & 8 & $28.6(10.1$ to 47.1$)$ & \\
\hline & A lot & 14 & 7.8 (3.6 to 12.0$)$ & 10 & 35.7 (16.2 to 55.2 ) & \\
\hline \multirow[t]{6}{*}{ Anxiety and distress $(\mathrm{N}=206)$} & & $\mathrm{N}=178$ & & $\mathrm{~N}=28$ & & $0.013^{*}$ \\
\hline & Not at all & 59 & 33.1 (26.0 to 40.3 ) & 4 & 14.3 (4.0 to 32.7$)$ & \\
\hline & A little & 35 & $19.7(13.5$ to 25.8$)$ & 3 & 10.7 (2.3 to 28.2$)$ & \\
\hline & Some & 36 & 20.2 (14.0 to 26.4$)$ & 5 & 17.9 (6.1 to 36.9$)$ & \\
\hline & Quite a lot & 31 & 17.4 (11.6 to 23.3$)$ & 8 & $28.6(10.1$ to 47.1$)$ & \\
\hline & A lot & 17 & $9.6(5.0$ to 14.1$)$ & 8 & $28.6(10.1$ to 47.1$)$ & \\
\hline \multicolumn{7}{|l|}{ Family and social environment } \\
\hline \multirow{6}{*}{$\begin{array}{l}\text { The individual considers that his/her pain affects his/ } \\
\text { her family }(\mathrm{N}=206)\end{array}$} & & $N=178$ & & $\mathrm{~N}=28$ & & $0.013 \ddagger$ \\
\hline & Not at all & 98 & 55.1 (47.5 to 62.6$)$ & 10 & 35.7 (16.2 to 55.2$)$ & \\
\hline & A little & 25 & $14.0(8.7$ to 19.4$)$ & 2 & $7.1(0.9$ to 23.5$)$ & \\
\hline & Some & 31 & $17.4(11.6$ to 23.3$)$ & 6 & 21.4 (8.3 to 41.0$)$ & \\
\hline & Quite a lot & 17 & $9.6(5.0$ to 14.1$)$ & 9 & 32.1 (13.1 to 51.2$)$ & \\
\hline & A lot & 7 & $3.9(0.8$ to 7.1$)$ & 1 & $3.6(0.1$ to 18.3$)$ & \\
\hline \multirow{5}{*}{$\begin{array}{l}\text { The impact of pain on their relationships with friends } \\
(\mathrm{N}=206)\end{array}$} & & $\mathrm{N}=179$ & & $\mathrm{~N}=27$ & & $0.010 \ddagger$ \\
\hline & $\begin{array}{l}\text { The relationship has been lost because } \\
\text { of the pain }\end{array}$ & 4 & $2.2(0.6$ to 5.6$)$ & 3 & 11.1 (2.4 to 29.2$)$ & \\
\hline & The relationship has deteriorated & 29 & $16.2(10.5$ to 21.9$)$ & 9 & $33.3(13.7$ to 53.0$)$ & \\
\hline & Nothing has changed in the relationship & 145 & $81.0(75.0$ to 87.0$)$ & 15 & 55.6 (35.0 to 76.2 ) & \\
\hline & The relationship has improved & 1 & $0.6(0.0$ to 3.1$)$ & 0 & 0 & \\
\hline \multirow{6}{*}{$\begin{array}{l}\text { Satisfaction with the support received from the family } \\
(N=207)\end{array}$} & & $\mathrm{N}=179$ & & $\mathrm{~N}=28$ & & $0.206^{*}$ \\
\hline & Very unsatisfied & 4 & $2.2(0.6$ to 5.6$)$ & 0 & 0 & \\
\hline & Unsatisfied & 4 & $2.2(0.6$ to 5.6$)$ & 3 & 10.7 (2.3 to 28.2$)$ & \\
\hline & Neither satisfied nor dissatisfied & 32 & $17.9(12.0$ to 23.8$)$ & 6 & 21.4 (8.3 to 41.0$)$ & \\
\hline & Satisfied & 74 & 41.3 (33.8 to 48.8$)$ & 12 & $42.9(22.7$ to 63.0$)$ & \\
\hline & Very satisfied & 65 & $36.3(29.0$ to 43.6$)$ & 7 & 25.0 (7.2 to 42.8$)$ & \\
\hline
\end{tabular}


Table 5 Multivariate analysis of the factors related to leaving or losing employment

\begin{tabular}{|c|c|c|c|}
\hline Variables & $\begin{array}{l}\text { Wald } \\
\text { Statistics }\end{array}$ & OR $(95 \% \mathrm{Cl})$ & p Value \\
\hline \multicolumn{4}{|c|}{ Sadness due to their pain } \\
\hline $\mathrm{No}^{*}$ & & & 0.059 \\
\hline Yes & 3.57 & 4.25 (0.95 to 19.02$)$ & \\
\hline \multicolumn{4}{|c|}{ Opinion on the care received } \\
\hline Unsatisfied* & & & 0.032 \\
\hline Satisfied & 4.57 & $2.60(6.25$ to 1.08$)$ & \\
\hline $\begin{array}{l}\text { Number of } \\
\text { medical } \\
\text { consultations }\end{array}$ & 4.11 & 1.09 (1.00 to 1.19$)$ & 0.043 \\
\hline
\end{tabular}

this relationship was inverted in our study and the individuals who requested more sick leave were those with a higher educational level. One possible explanation for this is that employees with a lower education level and worse qualifications felt more insecure and were more afraid of losing their jobs. As such, they tend to remain at work even though their health is not optimal. ${ }^{35}$

Regarding the second issue analysed in this study, it is noteworthy that negative mood was associated with job loss. This result is consistent with data from other studies where patients who suffer from CP and experience a mood disorder were those who reported more physical limitations. ${ }^{36}$ In addition, these patients were three times more likely to be absent from their jobs ${ }^{37}$ and to be less productive ${ }^{38}$ than those without such disorders. Moreover, the number of medical consultations increases when CP and depression coexist. ${ }^{39}{ }^{40}$ In the present study, the individuals with most medical consultations were at greater risk of having lost their jobs, which may be explained by the high percentage of people who felt sad because of the pain.

Dissatisfaction with the care received also had a direct effect on job loss in CP sufferers. This relationship has not been described previously and it could be explained by the hypothesis that individuals who suffer from mood disorders are less capable of positively valuing their environment, including their healthcare. Accordingly, these individuals are more likely to be dissatisfied with the medical attention they receive and they will therefore use more healthcare resources to resolve their problems. ${ }^{41}$ This finding underlines the importance of appraising and properly treating the psychological domain in people with $\mathrm{CP}$, which as well as helping to improve their therapeutic response could also produce greater satisfaction and less use of the healthcare resources, also dampening the negative impact on their jobs. However, further studies will be necessary to better understand of this association.

Some limitations of the present study must be taken into account. First, a suitable sample size was not determined in advance as the study is a post hoc analysis of data collected previously, which may reduce the precision of the specific parameters evaluated. Another limitation is that the information was gathered via telephone interviews with an established maximum duration of $\sim 20 \mathrm{~min}$ to prevent the loss of responders. This limits the complexity of the questionnaire and as such, no information was included regarding the individual's workload or aspects related to presenteeism, nor on the type of drugs taken as pain relief medication. The survey used was not validated, but the items included in the questionnaire were taken from other surveys carried out by the 'Instituto Nacional de Estadística' (National Statistics Institute) in Spain, which follow adequate quality control procedures. No specific scales were used to assess sadness and anxiety as the nature of telephone interviews makes it difficult to implement such instruments. Some authors have argued that the use of telephone interviews is more suitable for population-based studies than for face-to-face surveys, since they permit greater coverage, and that more representative samples are obtained by selecting telephone numbers at random. Finally, it must be borne in mind that this is a cross-sectional study and thus, the relationships observed do not allow us to establish a causal relationship.

In conclusion, despite the limitations cited above, the results of this study highlight the strong impact of $\mathrm{CP}$ on employment in the Spanish population. In addition, the results also provide new insights into other issues that have not been analysed previously, such as the effect that the perceived impact of pain on the family has on the individual's performance at work.

Acknowledgements The authors would like to acknowledge the effort of the interviewers who collected the data through the telephone interviews.

Contributors IF conceived the idea of the article. The fieldwork was performed by BO, AS and MD. MD and HdS performed the statistical analysis. HdS was mainly responsible for writing the manuscript. IF and AS were involved in revising the content. All the authors approved the final version of the manuscript.

Funding This work was supported by the External Chair of Pain, a collaboration between the University of Cádiz and the Grünenthal Foundation. The Grünenthal Foundation is a private non-profitable organisation that promotes the dissemination of scientific knowledge and supports research.

\section{Competing interests None declared}

Provenance and peer review Not commissioned; externally peer reviewed.

Data sharing statement No additional data are available.

Open Access This is an Open Access article distributed in accordance with the Creative Commons Attribution Non Commercial (CC BY-NC 4.0) license, which permits others to distribute, remix, adapt, build upon this work noncommercially, and license their derivative works on different terms, provided the original work is properly cited and the use is non-commercial. See: http:// creativecommons.org/licenses/by-nc/4.0/

\section{REFERENCES}

1. Breivik $H$, Collett $B$, Ventafridda $V$, et al. Survey of chronic pain in Europe: prevalence, impact on daily life, and treatment. Eur J Pain 2006;10:287-333.

2. Dueñas $M$, Salazar A, Ojeda B, et al. A nationwide study of chronic pain prevalence in the general Spanish population: identifying clinical subgroups through cluster analysis. Pain Med 2014;16:811-22. 
3. Sadosky AB, Taylor-Stokes G, Lobosco S, et al. Relationship between self-reported low-back pain severity and other patient-reported outcomes. J Spinal Disord Tech 2011;26:8-14.

4. Sadosky AB, Dibonaventura M, Cappelleri JC, et al. The association between lower back pain and health status, work productivity, and health care resource use in Japan. J Pain Res 2015;25:119-30.

5. Poole $\mathrm{H}$, White $\mathrm{S}$, Blake $\mathrm{C}$, et al. Depression in chronic pain patients: prevalence and measurement. Pain Pract 2009;9:173-80.

6. Ojeda B, Salazar A, Dueñas M, et al. The impact of chronic pain: the perspective of patients, relatives, and caregivers. Fam Syst Health 2014;32:399-407.

7. Mesas AE, González AD, Mesas CE, et al. The association of chronic neck pain, low back pain and migraine with absenteeism due to health problems in Spanish workers. Spine 2014;39:1243-53.

8. Azevedo LF, Costa-Pereira A, Mendonc L, et al. The economic impact of chronic pain: a nationwide population-based cost-of-illness study in Portugal. Eur J Health Econ 2016;17:87-98.

9. North RB, Shipley J, Wang $\mathrm{H}$, et al. A review of economic factors related to the delivery of health care for chronic low back pain. Neuromodul Technol Neural Interface 2014;17:69-76.

10. Raftery MN, Ryan P, Normand C, et al. The economic cost of chronic noncancer pain in Ireland: results from the PRIME study, part 2. J Pain 2012;13:139-45.

11. Gustavsson A, Bjorkman J, Ljungcrantz C, et al. Socio-economic burden of patients with a diagnosis related to chronic pain-register data of 840,000 Swedish patients. Eur J Pain 2012;6:289-99.

12. Pérez C, Navarro A, Saldaña MT, et al. Modelling the predictive value of pain intensity on costs and resources utilization in patients with peripheral neuropathic pain. Clin J Pain 2015;31:273-9.

13. Ruiz CA, Alonso MBM. Crisis económica española y salud. Impacto clínico en el dolor crónico. Rev Soc Esp Dolor 2015;22:51-8.

14. de Buck PDM, de Bock GH, van Dijk F, et al. Sick leave as a predictor of job loss in patients with chronic arthritis. Int Arch Occup Environ Health 2006;80:160-70.

15. Guillory J, Chang P, Henderson CR, et al. Piloting a text message-based social support intervention for patients with chronic pain. Clin J Pain 2015;31:548-56.

16. Jamison RN, Virts KL. The influence of family support on chronic pain. Behav Res Ther 1990;28:283-7.

17. Mccluskey S, Brooks J, King N, et al. The influence of 'significant others' on persistent back pain and work participation: a qualitative exploration of illness perceptions. BMC Musculoskelet Disord 2011;:12:236.

18. Brooks J, McCluskey S, King N, et al. Illness perceptions in the context of differing work participation outcomes: exploring the influence of significant others in persistent back pain. $B M C$ Musculoskelet Disord 2013;14:48.

19. McCluskey S, Brooks J, King N, et al. Are the treatment expectations of 'significant others' psychosocial obstacles to work participation for those with persistent low back pain? Work 2014;48:391-8.

20. Hermsen LA, Leone SS, van der Windt DA, et al. Functional outcome in older adults with joint pain and comorbidity: design of a prospective cohort study. BMC Musculoskelet Disord 2011;12:241.

21. Miró J, Paredes S, Rull M, et al. Pain in older adults: a prevalence study in the Mediterranean region of Catalonia. Eur J Pain 2007;11:83-92

22. Instituto Nacional de Estadística (INE). Encuesta Nacional de Salud 2006. 2006. http://www.ine.es/metodologia/t15/ens_adu06.pdf (accessed 26 Nov 2010)

23. Instituto Nacional de Estadística (INE). Encuesta sobre Discapacidades, Autonomía personal y situaciones de
Dependencia. 2008. http://www.ine.es/daco/daco42/discapa/edad cui.pdf (accessed 26 Nov 2010).

24. Poulain P, Langlade A, Goldberg J. Cancer pain management in the home. Pain Clin Update 1997;V:1-8.

25. Kovacs FM, Fernández $\mathrm{C}$, Cordero A, et al. Non-specific low back pain in primary care in the Spanish National Health Service: a prospective study on clinical outcomes and determinants of management. BMC Health Serv Res 2006;6:57.

26. Choy E, Perrot S, Leon T, et al. A patient survey of the impact of fibromyalgia and the journey to diagnosis. BMC Health Serv Res 2010;10:102.

27. Maetzel A, Li L. The economic burden of low back pain: a review of studies published between 1996 and 2001. Best Pract Res Clin Rheumatol 2002;16:23-30.

28. Jacobi CE, van den Berg B, Boshuizen $\mathrm{HC}$, et al. Dimension-specific burden of caregiving among partners of rheumatoid arthritis patients. Rheumatology (Oxford) 2003;42:1226-33

29. Kowal J, Wilson KG, McWilliams LA, et al. Self-perceived burden in chronic pain: relevance, prevalence, and predictors. Pain 2012;153:1735-41.

30. De Vries HJ, Reneman MF, Groothoff JW, et al. Workers who stay at work despite chronic nonspecific musculoskeletal pain: do they differ from workers with sick leave? J Occup Rehabil 2012;22:489-502.

31. Robinson JP, Dansie EJ, Wilson HD, et al. Attitudes and beliefs of working and work- disabled people with chronic pain prescribed. Pain Med 2015;16:1311-24.

32. Suoyrjo $\mathrm{H}$, Hinkka $\mathrm{K}$, Oksanen $\mathrm{T}$, et al. Effects of multidisciplinary inpatient rehabilitation for chronic back or neck pain: a register-linkage study of sickness absences and analgesic purchases in an occupational cohort. Occup Environ Med 2008;65:179-84.

33. Denison E, Åsenlöf P, Lindberg P. Self-efficacy, fear avoidance, and pain intensity as predictors of disability in subacute and chronic musculoskeletal pain patients in primary health care. Pain 2004;111:245-52.

34. Fuss I, Angst F, Lehmann S, et al. Prognostic factors for pain relie and functional improvement in chronic pain after inpatient rehabilitation. Clin J Pain 2014;30:279-85.

35. Zakrzewska K. Presenteeism-unhealthy extra presence in the workplace. Przegl Epidemiol 2014;68:77-80, 157-9.

36. Outcalt SD, Kroenke K, Krebs EE, et al. Chronic pain and comorbid mental health conditions: independent associations of posttraumatic stress disorder and depression with pain, disability, and quality of life. J Behav Med 2015;38:535-43.

37. Munce SEP, Stansfeld SA, Blackmore ER, et al. The role of depression and chronic pain conditions in absenteeism: results from a national epidemiologic survey. J Occup Environ Med 2007;49:1206-11.

38. Li X, Gignac MA, Anis A. Workplace, psychosocial factors, and depressive symptoms among working people with arthritis: a longitudinal study. J Rheumatol 2006;33:1849-55.

39. Agüera L, Failde I, Cervilla JA, et al. Medically unexplained pain complaints are associated with underlying unrecognized mood disorders in primary care. BMC Fam Pract 2010;11:17.

40. Wong WS, Chow YF, Chen PP, et al. A longitudinal analysis on pain treatment satisfaction among Chinese patients with chronic pain: predictors and association with medical adherence, disability, and quality of life. Qual Life Res 2015;24:2087-97.

41. Bair MJ, Kroenke K, Sutherland JM, et al. Effects of depression and pain severity on satisfaction in medical outpatients: analysis of the Medical Outcomes Study. J Rehabil Res Dev 2007;44:143-52. 